\title{
Water desalination and purification using desalination units powered by solar panels
}

\author{
Hasan F. Khazaal ${ }^{1}$, Haider Th. Salim Alrikabi ${ }^{2 *}$, Faisal The yab Abed ${ }^{3}$, Salah Ibrahim Kadhm ${ }^{4}$ \\ ${ }^{1,2,4}$ Wasit University-college of Engineering - Electrical En gineering Department \\ ${ }^{3}$ University of Wasit
}

\section{Article Info}

Received, 2019

\section{Keyword:}

Desalination units,

Wind energy,

Solar energy,

Wind turbines,

Solar panels

\begin{abstract}
One of the problems of the south area in Iraq is the reduced of quantity and the lack of quality of the supplied water, especially in the remote areas. This problem is caused due to many reasons. One of these reasons is the decrease of supplied electricity, which reflected on the performance of water pumping and desalination stations. This paper presenting a project that presented to municipality of Al-Nasiriya city to overcome the problem of the lack in quantity and quality of the supplied water to some villages that remote from the center of the city, through the use of complex modules that consists of small renewable power station with desalination unit. The project goes through some stages starting from collecting the data that related to the aim of the project like; sun radiation level, wind speed, dust quantity, quality and quantity of the presented water, and the type of activity in the area. The collected data were analyzed and evaluated and then the decision comes to execute three complex modules in three locations, powered by small solar energy unit in each. The operation of these modules gives good results, where they offers an acceptable quality with sufficient quantity of water and this an encourage results to populate this experiment in remote areas.
\end{abstract}

\section{Corresponding Author:}

Haider Th. Salim Alrikabi

Electrical Engineering Department, College of Engineering

Wasit University,

Email: hdhiyab@uowasit.edu.iq

\section{Introduction}

The continuing decrease in water resources in the south of Iraq presents the problem of lack in quality of water in rivers because of the rise of salt concentration. This problem goes to the worst; because it is accompanied with the problem of decreasing the supplied electrical power to the same area. The two problems were reflected on the economy and the whole life of people who lived there. In addition, it is affecting their activities, especially the activities in the sector of agriculture; that it is decreasing the agrarian areas; also, it is 
affecting the health of living beings there, through the decrease in quality and quantity of healthy water used for domestic purposes, and this situation ringing the bell of serious problem. To mitigate this complex problem; it must be finding a comprehensive remedy by the use of resources that have a direct relation to it, in order to formulate an alternative solution to treat it.

The aim of this paper is to propose a complex module that consists of desalination unit and hybrid electrical supplying unit based on renewable energy (i.e. wind and solar energy). The suggested module is a trial to offer simple and reliable solution to pre defined problem in minimum cost.

\section{Related works}

Many researches that have been proposed to cover and solve the problem of supplying the electricity to remote areas. In [1,2] an evaluation studies that carried out to evaluate the economical use of renewable energy to operate small-scale water production in remote areas. In [3,4], a simulation studies have been proposed, where the authors investigating the techno-economic impact of uses a hybrid system (wind and solar) to supply the energy to cattle's farm. The assessment was done using three different software optimization scenarios in order to assess the system configuration and its impact on the tradeoff of technical and economic balance of the farm. In [5] a thesis on using a green house and integrated water desalination for arid area has been proposed. In this research, the use of the house's roof is suggested as a collector to collect the solar radiation in order to use it for evaporating fresh water from saline water. The fresh evaporated water is condensed and reserved to use it for irrigations and domestic applications. In [6] a study on using the solar and wind energy for supplying the electricity to small desalination plants in arid, desert, islands areas, because of its' (renewable energy) availability and its' cheap cost financially and environmentally compared with fossil fuel energy. In [7,8] Simulation studies that simulate hybrid renewable energy system used for operating small-scale desalination water plants have been proposed. The proposed system is used for supplying arid areas and islands by electricity for desalination water plants and household consumption. The simulation programs were used to optimize the design of the system as well as to manage the energy supply, energy storage, and cost analysis. From the preceded papers it can be seen that some of these studies are either simulation studies or it is done for one type of renewable energy system, which it is the solar energy only without investigating the use of wind energy system [9-12].

\section{Resources mapping}

The study is done in Thi-qar governorate, Nasiriya city, with cooperation with some state directorates like; management of water resources in Thi-qar governorate, management of water desalination, management of meteorological, ministry of environment and the ministry of transportation. The resources mapping start by the investigation and gathering data and information on all the circumstances that have a relation to the problem and the proposed study, especially which have an effect on the performance of wind turbine and solar cell panels, as well as the desalination units. The collected data subjected to some criterion such as:

- The sufficiency of energy resources to supply the energy to wind turbines and solar panels,

- The suitability of selected locations to execute the study,

- The availability of water resources and its' quantity and quality,

According to these criterions, various types of data have been collected, like; the geological nature of the area (i.e. sandy, rocky, or soily area), the nature of the water resources and its' quality, the kind of economic activity (i.e. industrial or agricultural, and domestics), and the conditions of weather; (i.e. The wind speed, the mean of sun shine, the dust, the dust storms, the humidity, and the mean of temperature) and all the conditions that have a relation and effect on the execution of the suggested module).

The results of the collected data are presenting in the following figures; 


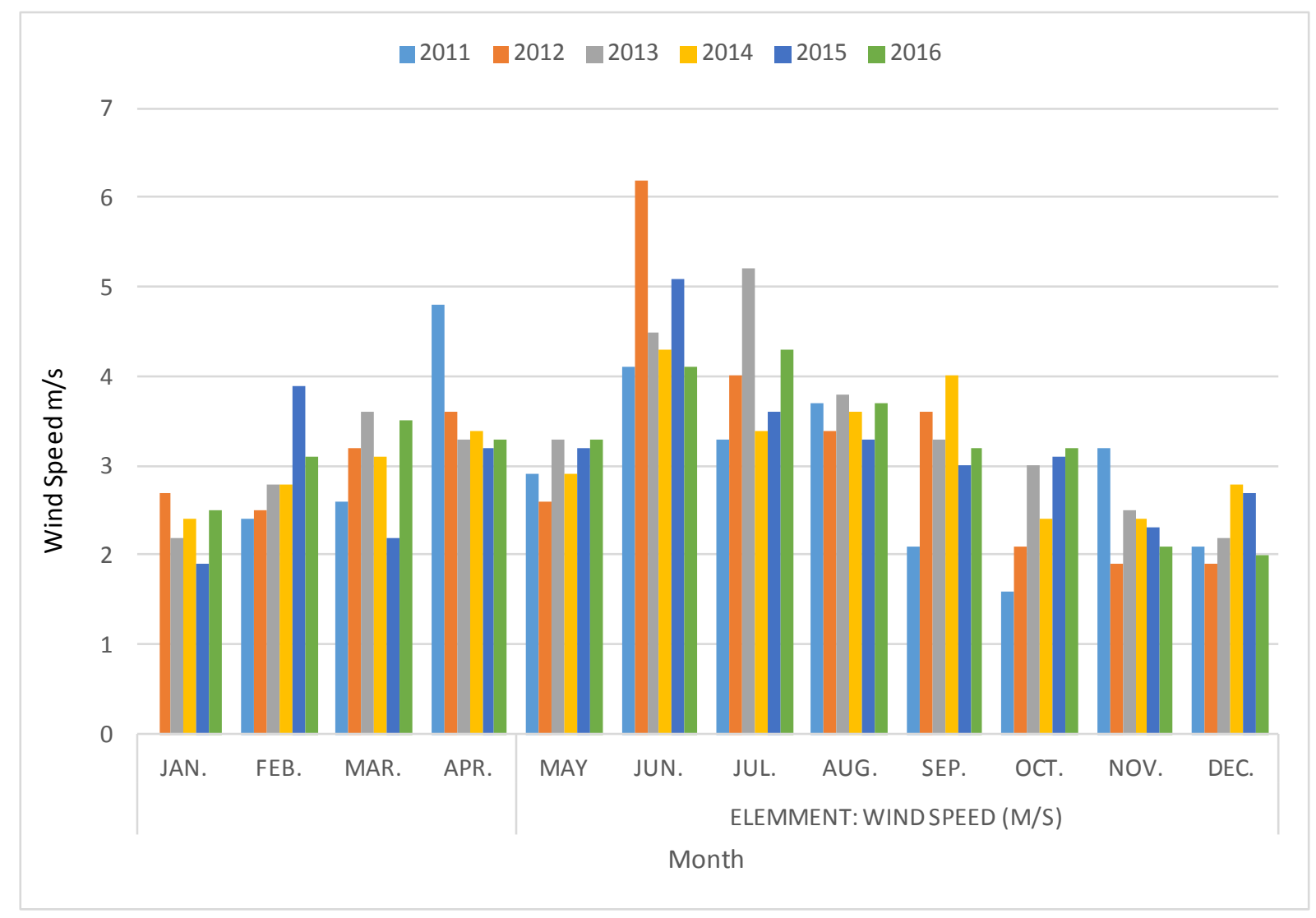

Fig. 1. The mean of wind speed of the period from 2011-2016

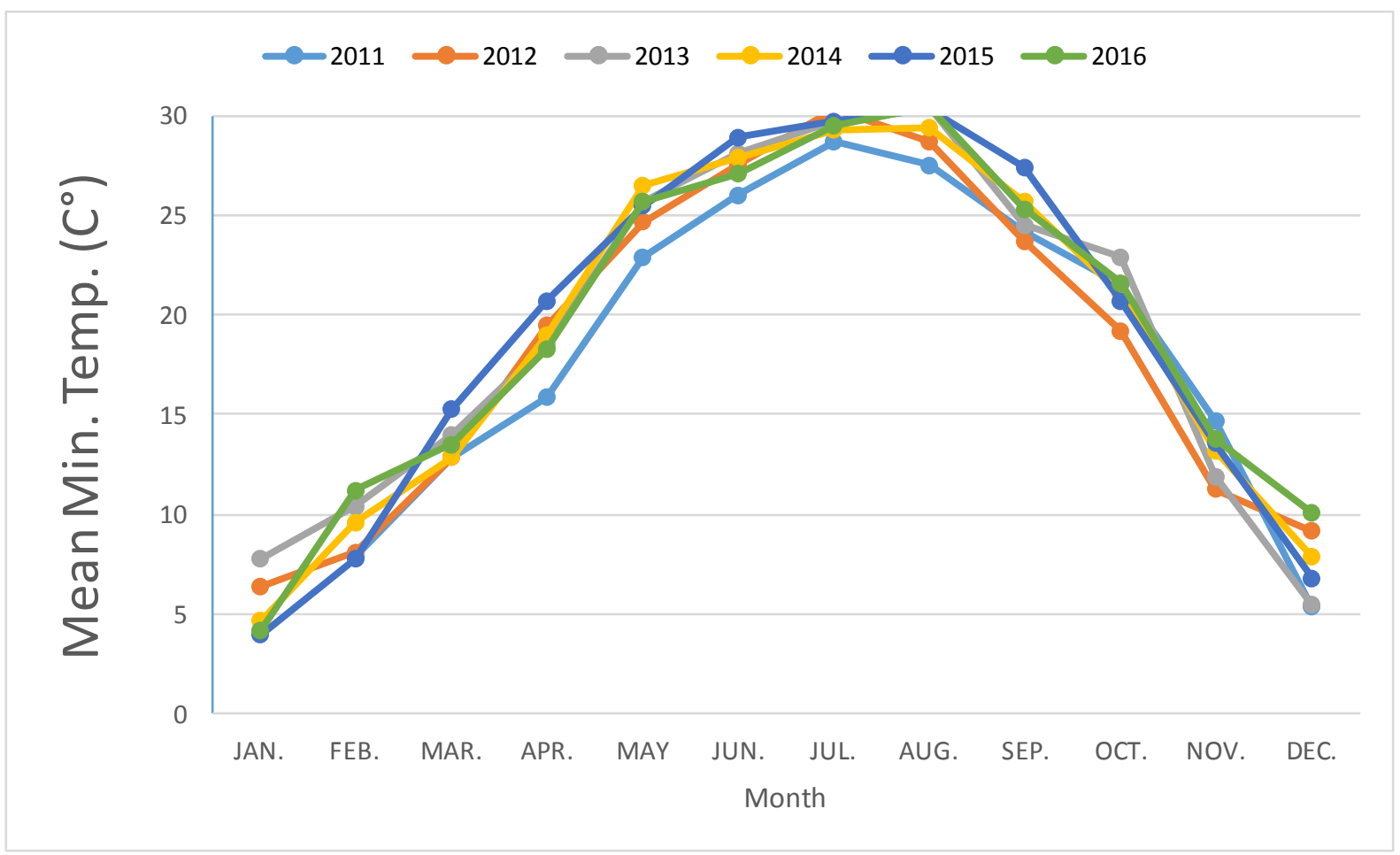

Fig. 2. The mean of minimum temperature of the period from 2011-2016 


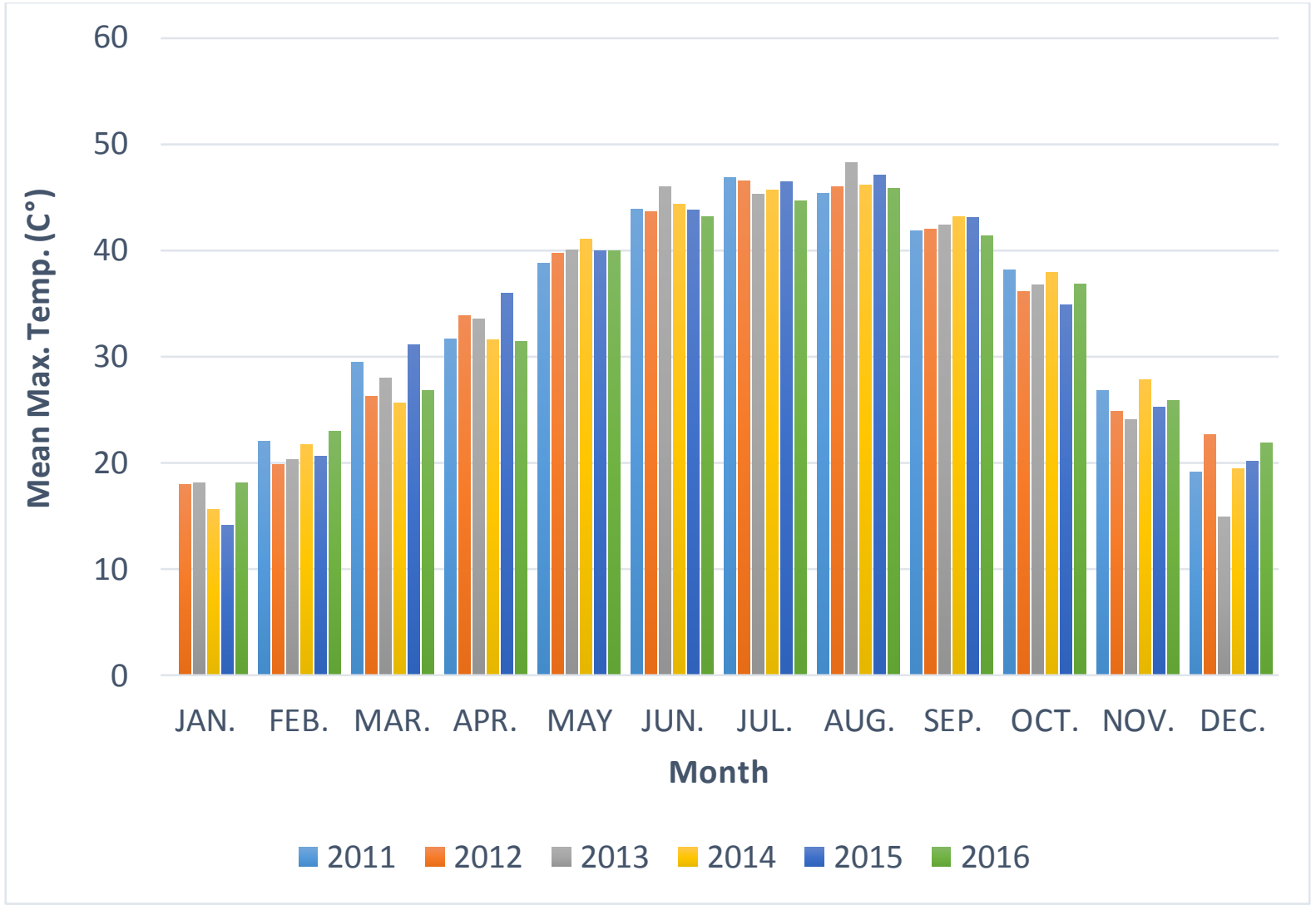

Fig. 3. The mean of maximum temperature of the period from 2011-2016

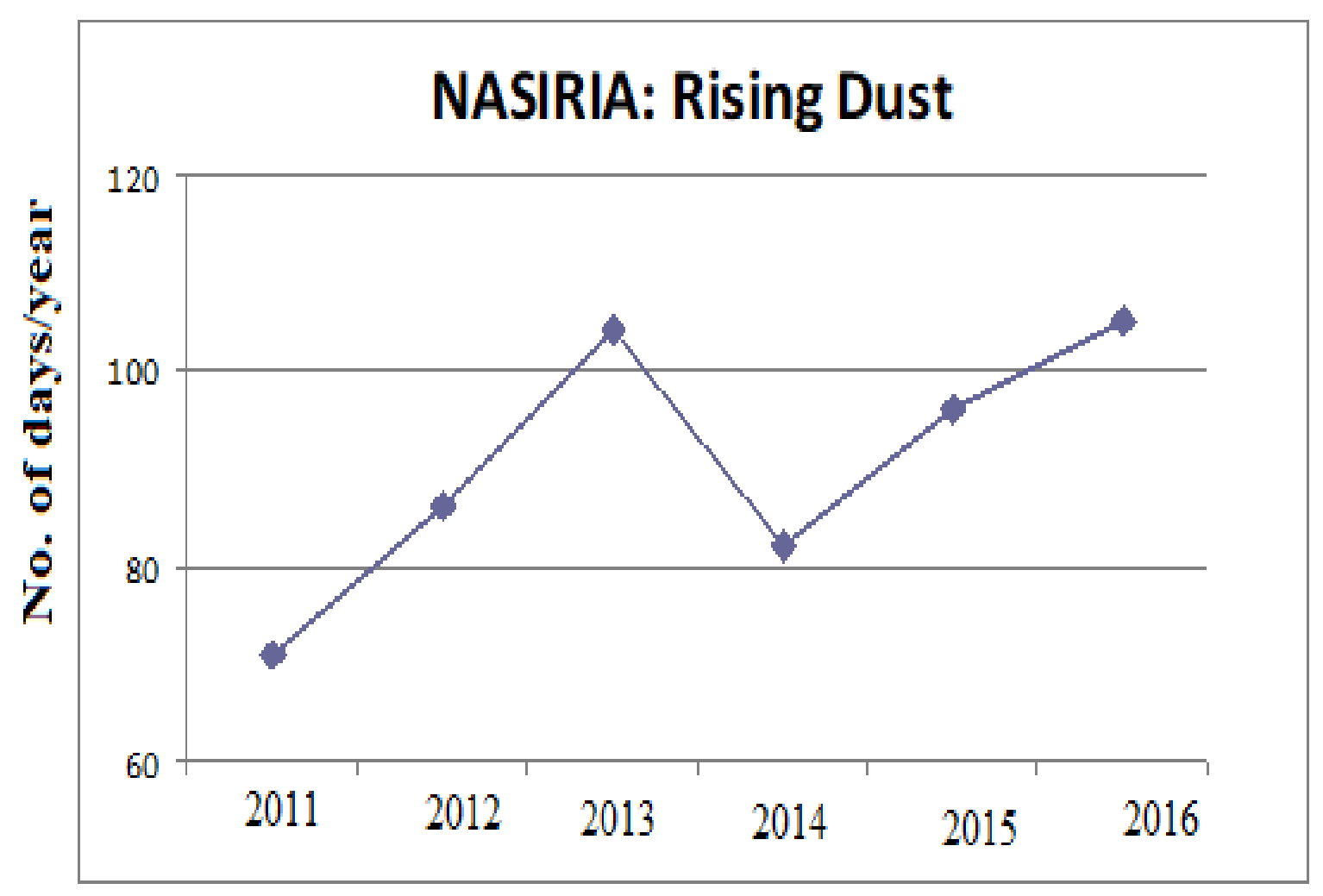

Fig. 4. The mean of raising dust of the period from 2011-2016 


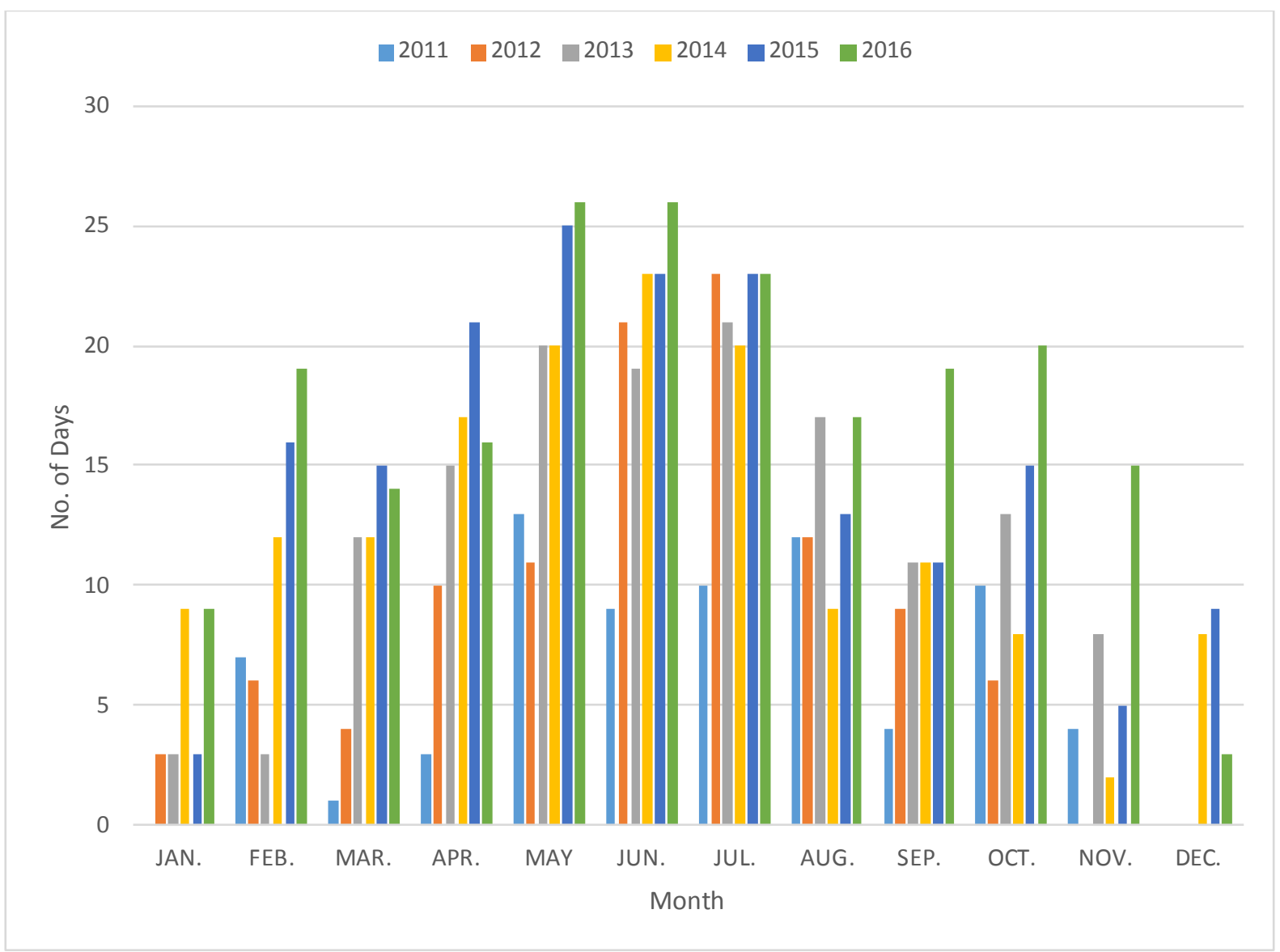

Fig. 5. The mean of suspended dust of the period from 2011-2016

\section{MONTHLY MEAN OFINCOMING RADIATION IN MWICM 2}

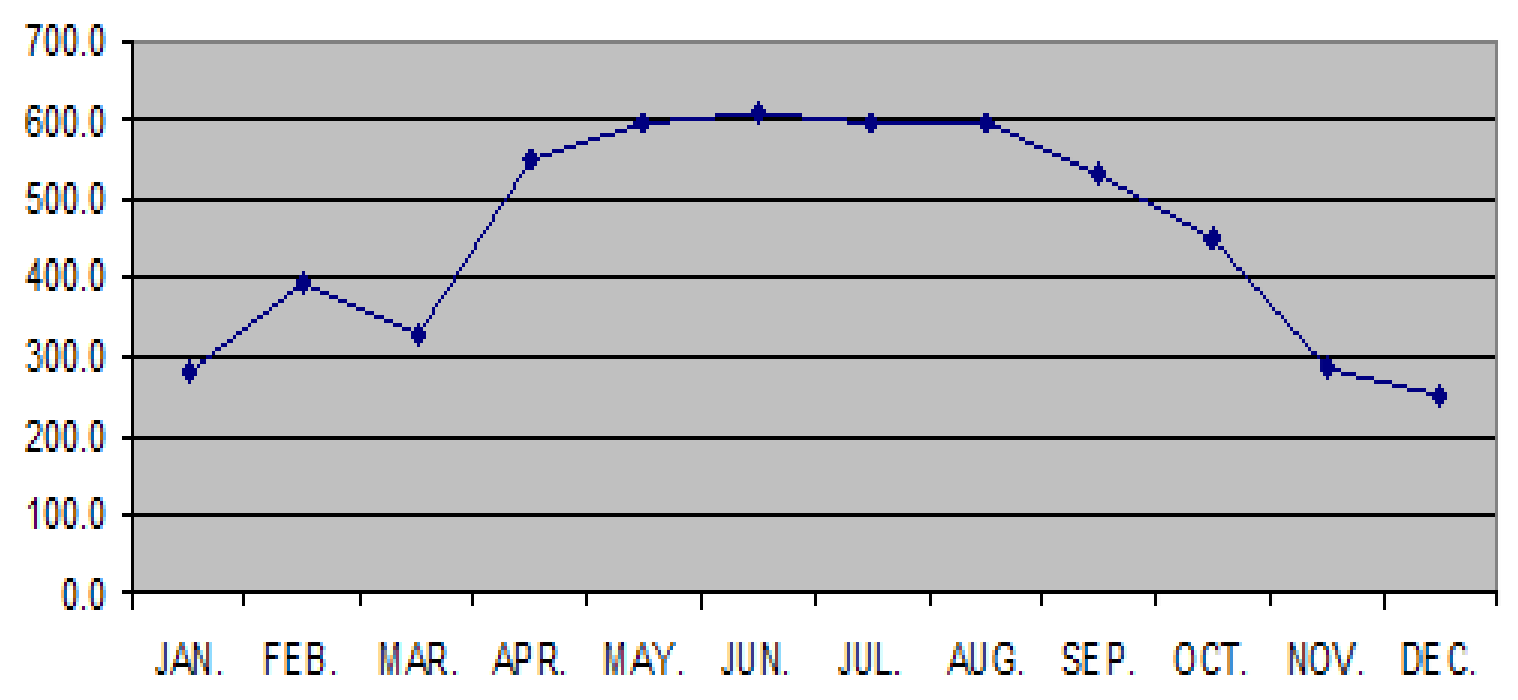

Fig. 6. The mean of monthly incoming radiation from the sun 


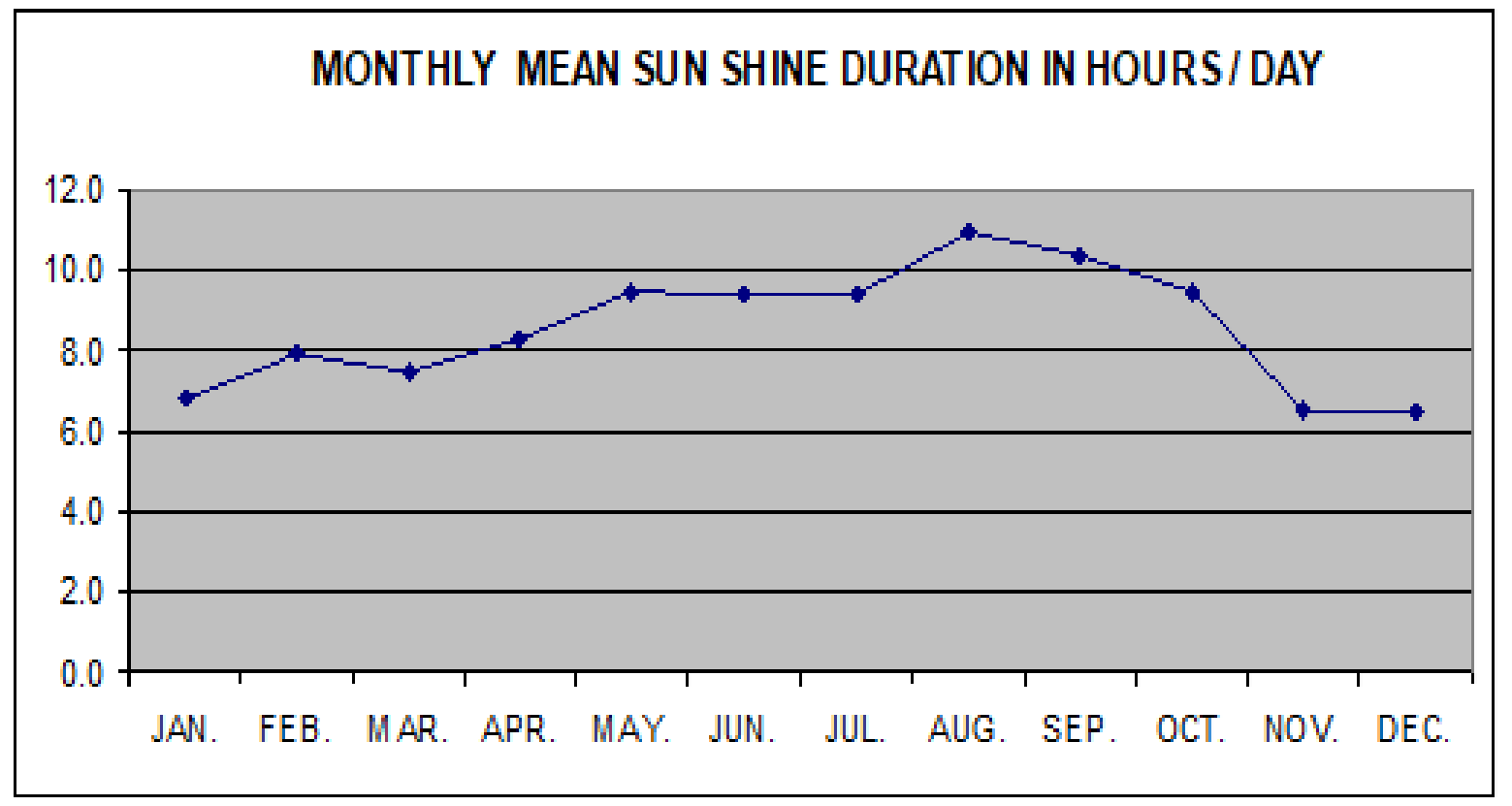

Fig. 7. The mean of monthly sun shine duration in hours per day

From figure 1, it can be seen that the mean of wind speed is not sufficient to rotate the wind turbines and this; disappoint the aim of the suggestion to build a hybrid station for generating an electrical power from various resources. Therefore, the focusing goes toward the generation of electrical power from solar energy only, i.e. the use of solar cell panels. The construction of solar cells panels' station must be complying with such conditions that affecting the performance of it. Figures 2-7 indicates the requested information about the weather condition, the duration of sunrises, incoming radiation, and the temperature level. The analysis of collected data proposes some challenges that disturbances the performance of solar panels, and must be faced it.

All the data comes positive and encouraged, except the data related to dust levels and the duration of its' occurrence, it comes negative, that the occurrence of dust is about 90 days per year and this will decrease the intensity of sunlight and then affecting the level of generating electricity. In addition, the accumulated dust on the panels will decrease its' performance and this will decrease the amount of generated electricity, this problem can be solved by the use of an off grid system, that using the batteries as storage bank, and continuing intensive cleaning of solar panels.

\section{Location selection conside rations'}

In addition to parameters that related to weather conditions, there are some parameters related to water conditions that must be considered when investigating on the suitable locations to construct desalination complex modules, especially at the remote areas which need the complex desalination units strongly. The parameters related to water conditions, are:

- The level of PH in raw water,

- The level of alkaline in raw water,

- The level of turbidity in raw water,

- The level of pollution of raw water by algae and reeds.

The inspections about the requested information have been done locally by selecting three remote locations, to have subjectively judgment on the quantity and quality of water resources to construct 
experimentally complex modules, which consists solar energy converter unit and desalination unit. The decision comes to investigate three locations. two of these locations were lie on small river that supplies water to industrial zone and some villages. The flow of this river is speedy a little bit. Therefore, it was selected one of these locations near the industrial area and the second location lies near one of the villages. The third location lies on a small river, which supplies water to some villages also, but the speed of the flow of this river is very slow. The properties of raw water of the three selected locations, according to the pre-tests are as follows; in the first location, the PH and magnesium quantity level in raw water are very high, in addition, there is a lot of dust in the air that this location lays near bricks factories, and this decreases the performance of solar panels significantly, leading to decrease the quantity of converted electricity needed to operate the desalination unit, and this presenting the need to extensive cleaning of the solar panel and the use of storage batteries, i.e. the proposed system must operate in an off grid condition, in the second location, the quality and quantity of water are in acceptable levels, finally the raw water of the third location has low turbidity but it contain a lot of algae and reeds.

According to gathered information, three complex modules with operation capacity of 5000 liters/hour were executed on the three pre-defined locations, and each is supported by reservoir of capacity of 10000 liter, in addition to batteries bank to continue the operation of the modules up to 24 hours. The three modules have been operated experimentally to have an over view on its performance to verify its efficiency by testing the quality and quantity of the produced water. The results of the experimental operation of the modules were tabulated in table 1.

Table 1. Physical and chemical analysis results of raw \& drink water of three locations

\begin{tabular}{|c|c|c|c|c|c|c|c|c|}
\hline \multirow[t]{2}{*}{ NO. } & \multirow{2}{*}{$\begin{array}{c}\text { analysis type \& } \\
\text { unit }\end{array}$} & \multicolumn{6}{|c|}{ Nature of sample } & \multirow{2}{*}{$\begin{array}{c}\text { Max. } \\
\text { permissible } \\
\text { level }\end{array}$} \\
\hline & & $\begin{array}{l}\text { No.(1) } \\
\text { raw }\end{array}$ & $\begin{array}{c}\text { No.(1) } \\
\text { purified }\end{array}$ & $\begin{array}{c}\text { No.(2) } \\
\text { raw }\end{array}$ & $\begin{array}{c}\text { No.(2) } \\
\text { purified }\end{array}$ & $\begin{array}{l}\text { No.(3) } \\
\text { raw }\end{array}$ & $\begin{array}{c}\text { No.(3) } \\
\text { purified }\end{array}$ & \\
\hline 1 & Turbidity(n.t.u) & 63.4 & 0.75 & 47.8 & 0.604 & 16.7 & 0.17 & 5 \\
\hline 2 & $\mathrm{PH}$ & 8.068 & 7.984 & 7.522 & 8.094 & 7.66 & 7.805 & $6.5-8.5$ \\
\hline 3 & $\begin{array}{c}\text { Electrical } \\
\text { conductivity } \\
(\mathrm{ms} / \mathrm{cm}) 25 \mathrm{c}^{\prime}\end{array}$ & 1002 & 920 & 1024 & 875 & 831 & 816 & 2000 \\
\hline 4 & $\begin{array}{l}\text { Total alkalinity } \\
\text { (as } \mathrm{CaCO} 3 \text { ) }\end{array}$ & 100 & 140 & 120 & 120 & 220 & 240 & $125-200$ \\
\hline 5 & $\begin{array}{c}\text { Total hardness (as } \\
\text { CaCO3) }\end{array}$ & 350.4 & 284.7 & 306.6 & 240.9 & 328.65 & 352.12 & 500 \\
\hline 6 & Calcium (as Ca) & 63 & 56.7 & $\overline{63}$ & 55.4 & 65.3 & 52.24 & 150 \\
\hline 7 & $\begin{array}{c}\text { Magnesium (as } \\
\mathrm{Mg} \text { ) }\end{array}$ & 46.29 & 28.6 & 35.7 & 24.5 & 39.69 & 53.16 & 50 \\
\hline 8 & Chloride (as CL) & 121.4 & 91.08 & 101.2 & 80.9 & 80.96 & 80.96 & 250 \\
\hline 9 & $\begin{array}{l}\text { Total dissolved } \\
\text { solids }\end{array}$ & 668 & 613 & 682 & 583 & 554 & 544 & 1000 \\
\hline 10 & $\begin{array}{c}\text { Sulphate } \\
\text { SO4) }\end{array}$ & - & - & - & - & - & - & 400 \\
\hline 11 & $\begin{array}{l}\text { Aluminium } \\
\text { (as AL) }\end{array}$ & - & - & - & - & - & - & 0.2 \\
\hline
\end{tabular}




\section{Conclusions}

After the execution of the project, some of the conclusions are present,

1- It could not use the wind turbine in Nasiriya city because the speed of the wind is not sufficient to rotate the blades of turbines, therefore it cannot be use the hybrid system to convert the wind and solar energy to electricity (i.e. it can be use only solar panels to get the electricity).

2- It can be use an on grid or off grid system, according to the nature of the location, the weather condition, and the quantity of the available water.

3- The water which produced by the first module is convenient to all purposes. but the quantity of the purified water is less than the module operation capacity because of the accumulated dust on the solar panels, that's why we use the storage batteries, that the batteries will guarantee the operation of the module on the whole day to cover the needs of consumers. Whereas the water that produced in the second module is suitable to all purposes, and its quantity is sufficient to cover the needs of consumers. While the water, which produced in the third module, is suitable to industrial and agrarian use only. Because the levels of alkaline and Magnesium are very high, as well as it has bad smell because of the highly level of algae and reeds and the problem of potable water for domestically uses could be solved by digging well.

4- Some of the remote areas are not qualified to construct the proposed system, due to some reasons like; the effect of industrial activity, the nature of water resources, that sometimes the available water source is not valid to use as potable water, therefore there is a need to digging wells.

5- The presented project were solve the problem of the three locations with low cost and simple equipments so it can be populated to all remote areas according to its resources.

The following figures presenting photos from the project.

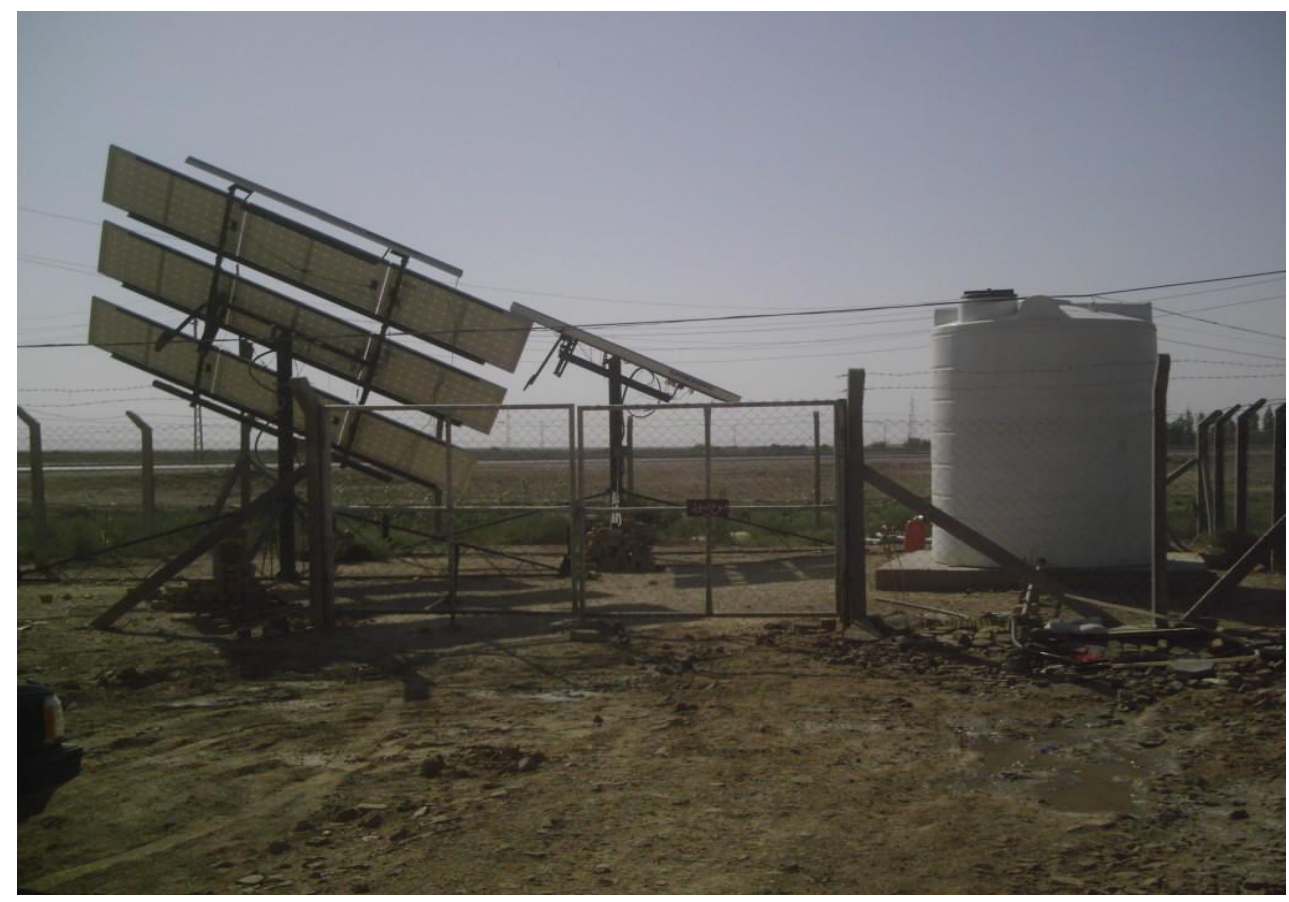

Fig. 8. Solar panels and 10000 liters water reservoir 


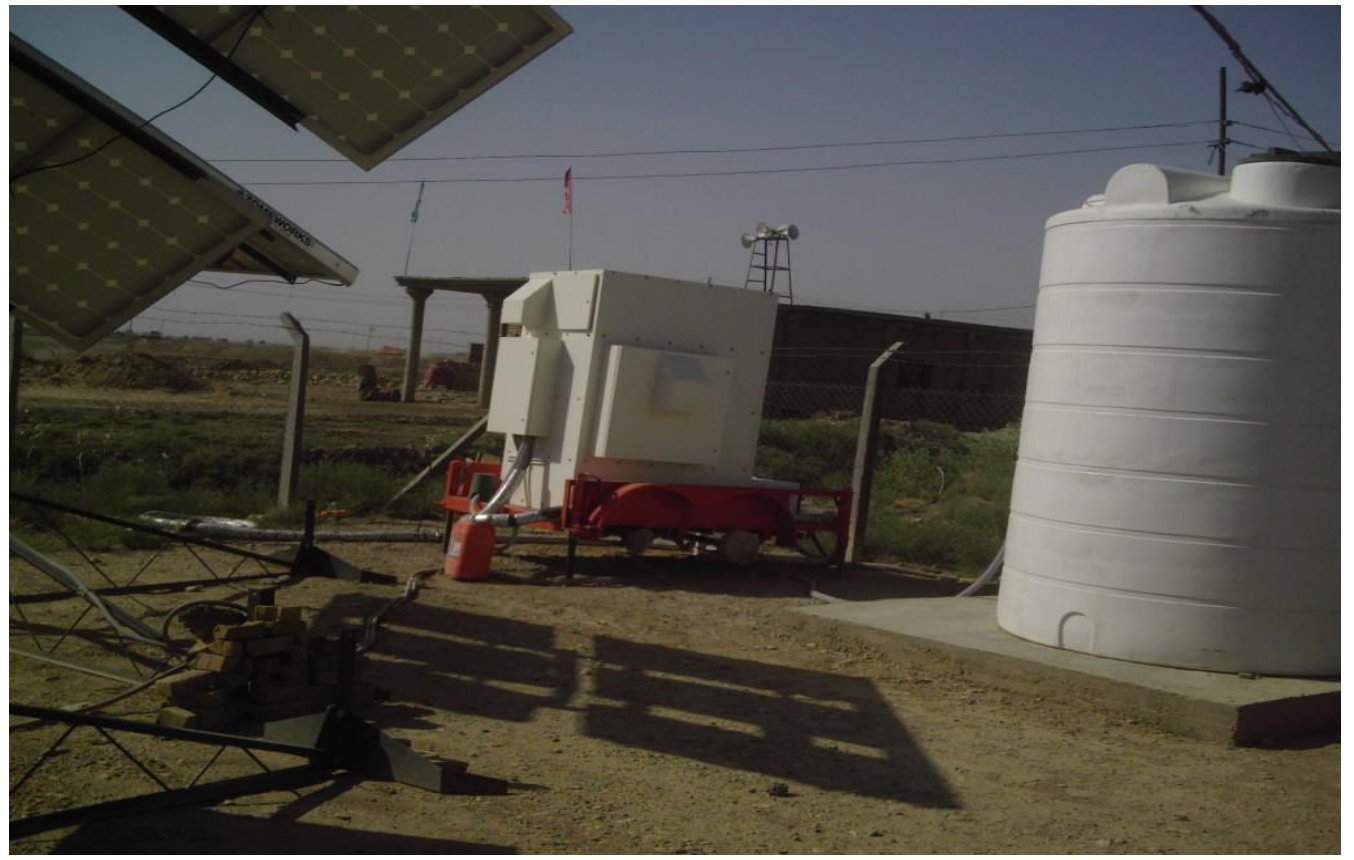

Fig. 9. Desalination unit and reservoir with solar panel

\section{Acknowledgement}

The proposed work would not been completed without the support of some state directorates, which are, management of water resources in Thi-qar governorate, management of water desalination, management of meteorological in Thi-qar governorate, ministry of environment and the ministry of transportation in which they presenting all the needed information. Many thanks to all of them, for their fruitful support .

\section{References}

[1] R. C. Ramírez , C. Recalde ," Small-Scale of Water Production Using Renewable Energy: Economic Evaluation", proceeding of the 7th International Conference on Applied Energy - ICAE2015, ScienceDirect Energy Procedia, No. 75, pp. 956 - 962, 2015.

[2] K. Akella, R. P. Saini, and Mahendra Pal Sharma. "Social, economical and environmental impacts of renewable energy systems." Renewable Energy 34.2 (2009): 390-396.

[3] T. Nacer T., A. Hamidat, O. Nadjemi , Techno-economic impacts analysis of a hybrid grid connected energy system applied for a cattle farm, Proceeding of the 7th International Conference on Applied Energy - ICAE2015, ScienceDirect Energy Procedia , No. 75, pp. 963 - 968, 2015.

[4] Hessami, Mir-Akbar, Hugh Campbell, and Christopher Sanguinetti. "A feasibility study of hybrid wind power systems for remote communities." Energy Policy 39.2 (2011): 877-886.

[5] Benjamin Durakovic, Selma Mesetovic, "Thermal Performances of Glazed Energy Storage Systems with Various Storage Materials: An Experimental study", Sustainable Cities and Society, Vol. 45, pp 422-430 (2019), ISSN: 2210-6707,

[6] M. T. Thameur,"Greenhouse Systems with Integrated Water Desalination for Arid Areas Based on solar Energy", Doctoral thesis, Department of Agricultural Biosystems and Technology, Swedish University of Agricultural Sciences, Alnarp 2003.

[7] H. R. Abdulshaheed, S. A. Binti, and I. I. Sadiq, "Proposed a Smart Solutions Based-on Cloud Computing and Wireless Sensing," Int. J. Pure Appl. Math., vol. 119, no. 18, pp. 427-449, 2018.

[8] D. Manolakos, G. Papadakis , D. Papantonis, S.Kyritsis, "A simulation-optimisation programme for designing hybrid energy systems for supplying electricity and fresh water through desalination to 
remote areas' Case study: the Merssini village, Donoussa island, Aegean Sea, Greece", Elsevier (pergamon) for Energy, No. 26, pp. 679-704, 2001.

[9] H. R. Bdulshaheed, Z. T. Yaseen, and I. I. Al-barazanchi, "New approach for Big Data Analysis using Clustering Algorithms in Information,” Jour Adv Res. Dyn. Control Syst., vol. 2, no. 4, pp. 11941197, 2019.

[10] M. F. Ariza Taba, M. Mwanza, N. S. Çetin, and K. Ülgen, "Assessment of the energy generation potential of photovoltaic systems in Caribbean region of Colombia," Period. Eng. Nat. Sci., vol. 5, no. 1, pp. 55-60, 2017. 